\title{
Hypothesis \\ Production of Recombinant Alpha-Synuclein: Still No Standardized Protocol in Sight
}

\author{
Mohammed Al-Azzani ${ }^{1}$ (D), Annekatrin König ${ }^{1}$ and Tiago Fleming Outeiro ${ }^{1,2,3,4, *}$ \\ 1 Department of Experimental Neurodegeneration, Center for Biostructural Imaging of Neurodegeneration, \\ University Medical Center Göttingen, Waldweg 33, 37073 Göttingen, Germany; \\ mohammed.alazzani@med.uni-goettingen.de (M.A.-A.); annekatrin.koenig@med.uni-goettingen.de (A.K.) \\ 2 Max Planck Institute for Experimental Medicine, 37075 Göttingen, Germany \\ 3 Translational and Clinical Research Institute, Faculty of Medical Sciences, Newcastle University, \\ Newcastle upon Tyne NE1 7RU, UK \\ 4 Scientific Employee with an Honorary Contract at German Center for Neurodegenerative Diseases (DZNE), \\ 37075 Göttingen, Germany \\ * Correspondence: tiago.outeiro@med.uni-goettingen.de; Tel.: +49-(0)551-39-13544
}

Citation: Al-Azzani, M.; König, A.; Outeiro, T.F. Production of

Recombinant Alpha-Synuclein: Stil No Standardized Protocol in Sight. Biomolecules 2022, 12, 324. https:// doi.org/10.3390/biom12020324

Academic Editor: François Ichas

Received: 22 December 2021

Accepted: 16 February 2022

Published: 18 February 2022

Publisher's Note: MDPI stays neutral with regard to jurisdictional claims in published maps and institutional affiliations.

Copyright: (C) 2022 by the authors. Licensee MDPI, Basel, Switzerland. This article is an open access article distributed under the terms and conditions of the Creative Commons Attribution (CC BY) license (https:// creativecommons.org/licenses/by/ $4.0 /)$.

\begin{abstract}
Synucleinopathies are a group of neurodegenerative diseases, characterized by the abnormal accumulation of the protein alpha-synuclein (aSyn). aSyn is an intrinsically disordered protein that can adopt different aggregation states, some of which may be associated with disease. Therefore, understanding the transitions between such aggregation states may be essential for deciphering the molecular underpinnings underlying synucleinopathies. Recombinant aSyn is routinely produced and purified from E. coli in many laboratories, and in vitro preparations of aSyn aggregated species became central for modeling neurodegeneration in cell and animal models. Thus, reproducibility and reliability of such studies largely depends on the purity and homogeneity of aSyn preparations across batches and between laboratories. A variety of different methods are in use to produce and purify aSyn, which we review in this commentary. We also show how extraction buffer composition can affect aSyn aggregation, emphasizing the importance of standardizing protocols to ensure reproducibility between different laboratories and studies, which are essential for advancing the field.
\end{abstract}

Keywords: alpha-synuclein; Parkinson's disease; aggregation; synucleinopathies; amyloid

\section{1. aSyn Species Are Widely Used in PD Research}

Alpha-Synuclein (aSyn) is a protein found in nerve terminals and in the nuclei in brain cells [1-3], although it is also present in red blood cells and other peripheral tissues including gastrointestinal tract and skin [4-9]. It is the main component of Lewy bodies and Lewy neurites, pathological hallmarks of Parkinson's disease (PD) and related synucleinopathies. aSyn is considered to be intrinsically disordered in its native state [4,10-12]. Soluble monomeric aSyn assembles into oligomeric species of different sizes and shapes. Oligomers transform into stable higher order assemblies rich in beta-sheet structures that bind certain fluorescent dyes such as Thioflavin T. The end-products of the assembly process are highly heterogenous with regards to their size, shape and availability to bind certain dyes $[13,14]$ and, despite growing controversy, are thought to play a role in synucleinopathies [15-17].

In addition to toxin-based and genetic models of PD, models based on injections of aggregated forms of aSyn have been developed. For this, monomeric recombinant aSyn is incubated in a well-defined manner to generate aggregated species consisting primarily of aSyn amyloid fibrils. These pre-formed fibrils (PFFs) are sonicated to produce shorter fibrils, enabling penetration of cell membranes and access to the cytosol. PFFs seed the aggregation of endogenous aSyn and trigger PD-like pathology in cell models, including phosphorylation at serine 129, and cell death [18-20]. Injection of aSyn PFFs into the dorsal 
striatum affects dopamine release and causes neurodegeneration and behavioral deficits that mimic alterations found in PD [21,22]. PFF-based models have been implemented in several groups although it has become apparent that the consistent production of aSyn PFFs is a major challenge and varies across laboratories [23]. Acknowledging this, the Michael J Fox Foundation established a set of guidelines that should be taken into consideration when using the PFFs model [23]. aSyn oligomerization and aggregation under different conditions have been widely studied in vitro. However, despite tremendous efforts, unexplained variations between experiments, batches, and laboratories, with regards to aggregation propensity of aSyn, remain a problem in the field.

\section{Putative Diagnostic Assays Based on aSyn Seeding and Aggregation}

aSyn seeding activity is being studied as a putative biomarker with diagnostic value since it differs markedly between patients and control brain or CSF. Seeding activity is usually detected using either a real-time quaking-induced conversion (RT-QuIC) or protein misfolding cyclic amplification (PMCA). Both are seed amplification assays (SAAs), based on the observation that misfolded aSyn in patient biospecimens can induce conformational change and aggregation of recombinant aSyn in vitro, in analogy to what was previously observed with the prion protein in prion diseases [24,25]. This seeded reaction amplifies pathological aSyn in biospecimens, allowing for detection of minute amounts of seed. In research settings, both methods show a high predictive power for PD diagnosis, thus, offering exciting possibilities for molecular diagnosis using accessible peripheral tissue. CSF analysis of PD patients results in sensitivity of $85-100 \%$ and $82-100 \%$ specificity [24,26-28].

Nonetheless, a number of problems need to be overcome for in vitro seeding assays to become routine screening techniques. The non-linear nature of the seed amplification is key for its high sensitivity, enabling the identification of minute amounts of aSyn seeds. On the other hand, slight variations in the assay conditions, including the substrate, can have a large impact on the assay kinetics. Besides the need to standardize protocols and sampling sites, production and purification of the recombinant aSyn as a substrate need to be standardized. Some studies use home-made aSyn, others use protein from commercial vendors. While batch-to-batch variations in aSyn are recognized as a possible source of variation in the field [28,29], only a subset of studies reports systematic comparison of interbatch variability [28,30-32]. In a recent study, SAAs were performed on control- and PD CSF by three independent groups in parallel according to their respective protocols [33]. The study confirmed the high diagnostic value of SAAs: PD was diagnosed with a sensitivity of $86-96 \%$ and specificity of $93-100 \%$ but reported high variability with regards to assay parameters (AUC maximum fluorescence, time to threshold) measured. A more robust measurement of these parameters could potentially enable correlation with clinical features, further increasing the diagnostic power of SAAs.

\section{3. aSyn Is Intrinsically Disordered}

Conformational changes and aggregation of aSyn are thought to be associated with PD and related synucleinopathies and have, therefore, been a subject of intense research [34]. As stated above, monomeric aSyn is viewed as an intrinsically disordered protein (IDP). Under physiological conditions, a number of studies showed that aSyn, in its free state, is present primarily as natively unfolded protein in different cells $[10,35,36]$. In addition, aSyn produced in E. coli and purified under denaturing or nondenaturing conditions is an unstructured monomer [4]. During the aggregation process, aSyn molecules cluster together into oligomeric species that can differ in size and shape. At least some of these oligomeric species (on pathway) can then rapidly assemble into larger beta-sheet rich fibrillar structures with amyloid properties. Interestingly, recent data suggest that these fibrillar amyloid structures appear to have different arrangements in different synucleinopathies, in different disease subtypes, or even between patients. Detailed studies revealed that aSyn preparations with distinct morphologies lead to different pathologies and the individual morphological characteristics of aSyn strains can be amplified and propagated in vivo 
and in vitro [13,15-17,37]. The fibril morphology of aSyn strains depends on a variety of parameters, including $\mathrm{pH}$ and salt content in the buffer used [14]. In addition, it was recently shown that even if aSyn of the same batch is set to aggregate under identical conditions, ThT negative fibrils may emerge along with ThT positive fibrils, in a random equilibrium [38].

\section{Varying Protocols Are in Use to Produce Recombinant aSyn}

aSyn used for in vitro studies has typically been produced in E. coli and purified using different protocols (Table 1). aSyn isolation protocols differ mainly in terms of protein expression, extraction, purification, and storage. Recombinant aSyn expression in E. coli is the first step in protein preparation. Before inducing protein expression, a starter culture is used to inoculate larger cultures volumes. Expression of aSyn from inducible promotors is initiated using IPTG. Although several labs induce protein expression for four hours, others induce for shorter periods or up to $16 \mathrm{~h}$. In addition, the IPTG concentration used varies and, in some protocols, it is not used at all, or not clearly stated. However, the induction time and/or IPTG concentration used likely affect the protein yield. Importantly, how these differences affect the dynamic ensembles of aSyn conformations and equilibrium has not been addressed.

Most differences among production protocols consider the second stage of protein preparation, i.e., aSyn extraction, which basically aims to separate the protein of interest from other unwanted bacterial proteins. Four extraction methods are commonly used for aSyn isolation. (1) One of the most commonly used methods is boiling $\left(95-100{ }^{\circ} \mathrm{C}\right)$ the bacterial pellet suspension. Given that aSyn is a natively unfolded and relatively thermostable protein, boiling will lead to denaturation and precipitation of most heat sensitive unwanted bacterial debris. Centrifugation removes most of these proteins in the pellet and keeps aSyn in the supernatant for the next purification steps. Boiling time and extraction buffers vary among several labs. Most laboratories use heat treatments for bacterial cell lysates for $5-15 \mathrm{~min}$, others for 20 or even $30 \mathrm{~min}$. Although aSyn is considered relatively thermostable, heat treatment could result in partial protein degradation with a longer boiling time [39]. The composition of the extraction buffer is considered important and can affect interactions of the protein of interest with other cells structures such as bacterial nucleic acids. Some groups use Tris buffer as the main extraction buffer, while many other groups include also salt (sometimes high salt) in the extraction buffer.

aSyn can also be isolated through (2) ammonium sulfate precipitation, (3) acid precipitation, or (4) periplasmic lysis. Furthermore, some purification protocols include a combination or more than one method as summarized in Table 1.

During purification, the 3rd phase of aSyn production, different chromatographic methods are employed to ensure a protein of high purity. Although aSyn is frequently purified in two successive chromatographic steps of ion-exchange chromatography (IEX) and size exclusion chromatography (SEC), it is purified many times by one chromatographic step of IEX. Furthermore, some research groups use SEC as the first purification step followed by IEX. Moreover, a third purification step of Reversed-Phase High-Pressure Liquid Chromatography (RP-HPLC) is used in some studies. Usually, two chromatographic steps are used to make sure aSyn prepared is monomeric and does not contain oligomeric or high ordered species. This variation in the number and/or order of purification steps will most likely affect the percentage of purity of the protein.

The way purified aSyn is handled and stored is of very high importance as it can affect the protein stability in terms of degradation or aggregation. After finishing all the isolation and purification steps, aSyn is either stored frozen or lyophilized. Lyophilization allows for longer storage but was shown to greatly affect the monomeric structure and variability in ThT-based aggregation assays [49]. 
Table 1. Overview over different protocols currently used for preparation and purification of recombinant aSyn protein.

\begin{tabular}{|c|c|c|c|c|}
\hline aSyn Expression & aSyn Extraction & Purification & Storage & Refs. \\
\hline $\begin{array}{l}\text { LB medium, } 1 \mathrm{mM} \text { IPTG, } \\
4 \mathrm{~h} \text { induction }\end{array}$ & $\begin{array}{l}40 \mathrm{mM} \text { Tris acetate buffer, sonication, } \\
\text { and } 10 \mathrm{~min} \text { boiling }\end{array}$ & IEX, SEC & Lyophilized & {$[4]$} \\
\hline TB medium, no IPTG, ON induction & $\begin{array}{l}\text { High salt buffer, sonication, and } 15 \\
\text { min boiling }\end{array}$ & SEC, IEX & Frozen & [19] \\
\hline $\begin{array}{c}\text { LB medium, } 1 \text { mM IPTG, } \\
5 \mathrm{~h} \text { induction }\end{array}$ & $\begin{array}{c}\text { Periplasmic lysis by osmotic } \\
\text { shock buffer }\end{array}$ & IEX & Lyophilized & [40] \\
\hline $\begin{array}{l}\text { LB medium, } 0.5 \mathrm{mM} \mathrm{IPTG}, \mathrm{ON} \\
\text { induction at } 25^{\circ} \mathrm{C}\end{array}$ & $\begin{array}{l}10 \mathrm{mM} \text { Tris lysis buffer, } 30 \text { min boiling, } \\
\text { and ammonium sulfate precipitation }\end{array}$ & IEX, SEC & Frozen & [37] \\
\hline IPTG, other details unstated & $\begin{array}{l}\text { Cell lysate precipitated in } \\
\text { ammonium sulfate }\end{array}$ & IEX, SEC & Lyophilized & [41] \\
\hline Details not stated & $\begin{array}{l}20 \mathrm{mM} \text { Tris and } 100 \mathrm{~mm} \mathrm{NaCl} \text {, } \\
\text { acid precipitation }\end{array}$ & IEX & Not stated & [42] \\
\hline $\begin{array}{c}\text { LB medium, } 1 \mathrm{mM} \text { IPTG, } \\
4 \mathrm{~h} \text { induction }\end{array}$ & $\begin{array}{l}\text { Periplasmic lysis by osmotic } \\
\text { shock buffer }\end{array}$ & IEX, HIC & Lyophilized & [43] \\
\hline $\begin{array}{l}\text { LB medium, } 1 \mathrm{mM} \text { IPTG, } \\
4 \mathrm{~h} \text { induction }\end{array}$ & $\begin{array}{c}20 \mathrm{mM} \text { Tris, sonication and } \\
15 \text { min boiling }\end{array}$ & IEX & Lyophilized & [44] \\
\hline $\begin{array}{l}\text { LB medium, IPTG concentration not } \\
\text { stated, } 4 \mathrm{~h} \text { induction }\end{array}$ & $\begin{array}{l}10 \mathrm{mM} \text { Tris, freeze-thaw, sonication, } \\
20 \text { min boiling, and ammonium } \\
\text { sulfate precipitation }\end{array}$ & IEX & Not stated & [14] \\
\hline $\begin{array}{c}\text { LB medium, } 0.5 \mathrm{mM} \mathrm{IPTG}, \mathrm{ON} \\
\text { induction at } 25^{\circ} \mathrm{C}\end{array}$ & $\begin{array}{l}500 \mathrm{mM} \mathrm{NaCl} \text { and } 100 \mathrm{~mm} \text { Tris, } 10 \\
\text { min boiling, and acid precipitation }\end{array}$ & IEX & Not stated & [45] \\
\hline $\begin{array}{l}\text { LB medium, } 0.44 \mathrm{mM} \text { IPTG, } 2 \mathrm{~h} \\
\text { induction at } 37^{\circ} \mathrm{C}\end{array}$ & $\begin{array}{l}10 \mathrm{mM} \text { Tris, freeze-thaw, sonication, } \\
\text { and ammonium sulfate precipitation }\end{array}$ & IEX, SEC & Not stated & [46] \\
\hline $\begin{array}{l}\text { TB medium, } 0.5 \mathrm{mM} \text { IPTG induction } \\
\text { for } 16 \mathrm{~h} \text { at } 37\end{array}$ & $\begin{array}{l}100 \mathrm{Mm} \text { tris and } 500 \mathrm{~mm} \mathrm{NaCl} \text {, } \\
\text { freeze-thaw, } 10 \text { min boiling, and } \\
\text { acid precipitation }\end{array}$ & RP-HPLC & Lyophilized & [47] \\
\hline $\begin{array}{c}\mathrm{LB} \text { medium at } 37^{\circ} \mathrm{C}, 4 \mathrm{~h} \mathrm{IPTG} \\
\text { induction }\end{array}$ & Sonication, $5 \mathrm{~min}$ boiling & $\begin{array}{l}\text { IEX, SEC, } \\
\text { RP-HPLC }\end{array}$ & Lyophilized & [48] \\
\hline $\begin{array}{c}\text { M9 medium at } 37^{\circ} \mathrm{C}, 1 \mathrm{mM} \text { IPTG } \\
\text { induction for } 4-5 \mathrm{~h}\end{array}$ & $\begin{array}{l}10 \mathrm{mM} \text { tris, sonication, } 20 \text { min boiling, } \\
\text { and ammonium sulfate precipitation }\end{array}$ & IEX, SEC & Frozen & [38] \\
\hline
\end{tabular}

In summary, aSyn purification methods in use vary in all stages of aSyn purification. aSyn purified with these methods is frequently used to generate PFFs or oligomeric species. Although aSyn is defined as a natively unfolded protein, it is of high importance to keep in mind that it exists as a dynamic ensemble of conformations. Some of these conformations are more aggregation prone than others. These conformations are affected by the surrounding environment which can affect the equilibrium among this dynamic ensemble of conformations [50]. It is still largely unknown how the different purification methods, and how variations within a certain method can affect the final equilibrium of the different conformations. We think that variations, even minor changes, can affect the protein surrounding environment and subsequently the distribution of the different conformations of monomeric protein leading to different aggregation propensities. A recently published systematic comparison of aSyn isolated via boiling, acid precipitation, ammonium sulfate precipitation, or periplasmic lysis revealed that the aggregation propensity is affected by the isolation method [51]. In this comparative study, the authors observed that aSyn extracted by periplasmic lysis and ammonium sulfate precipitation has a higher aggregation propensity, compared to aSyn extracted by boiling, or acid precipitation. However, so far, no study has systematically compared the impact of shorter (5-15 $\mathrm{min}$ ) heat-treatments that are used in most protocols $[4,19,44,47,51,52]$. In addition, different buffers are used to lyse the bacterial cells $[4,17,19,37,44,47,51]$, and their effects are largely unknown. 


\section{Variations in Purification Protocols Can Change the Outcome of Downstream Applications}

We provide here a practical example of how the lysate extraction buffer composition can affect the aggregation propensity of aSyn. While some protocols use a lysis buffer lacking sodium chloride $(\mathrm{NaCl})$ salt, others include up to $750 \mathrm{mM} \mathrm{NaCl}$. We lysed bacterial cells either in high salt buffer or no salt extraction buffer and compared the aggregation kinetics of aSyn after anion exchange chromatography (AEX) based on Thioflavin T (ThT) fluorescence sensitivity in 96-well plates. Importantly, before running the aggregation assays, we tested the purity of aSyn. Using sodium dodecyl sulphate-polyacrylamide gel electrophoresis (SDS-PAGE) and Coomassie staining, we detected only one band migrating above $15 \mathrm{kDa}$, corresponding to the monomeric state of the protein (Figure 1a). Before lyophilizing the protein purified by AEX, we analyzed an aliquot of each condition by size exclusion chromatography and detected mainly one peak in the gel filtration chromatogram, suggesting aSyn was essentially monomeric (Figure $1 \mathrm{~b}$ ). Shoulders just eluting before the monomeric fraction usually indicate the presence of multimers, here around $12 \mathrm{~mL}$ of elution volume. We also detected a small peak at $19 \mathrm{~mL}$ of elution volume in the "No salt" extracted aSyn. Although no protein was detected in this peak by SDS-PAGE (data not shown here), most likely due to very low abundance, we cannot rule out that a degradation product of aSyn is present, and that this may affect the aggregation. This could mean that salt might play a role in stabilizing aSyn during its extraction and purification. Detailed mass spectrometry analyses of the second peak might help further clarify this. Furthermore, it is important to keep in mind that, although ThT has been widely used to study protein aggregation and amyloid formation, recent studies showed that ThT reactivity is not necessarily a synonym of fibrilization or aggregation, as some types of fibrils are ThTnegative [38].

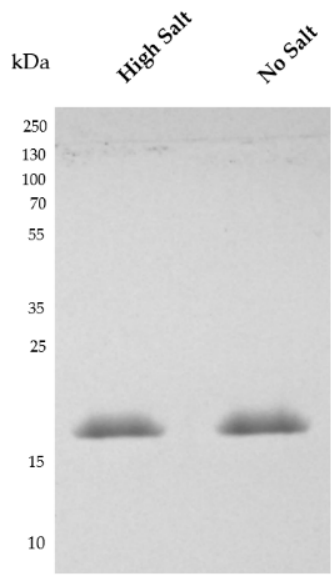

b

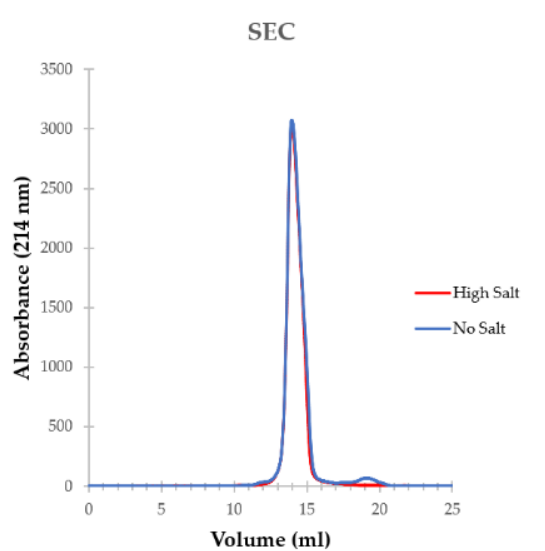

c

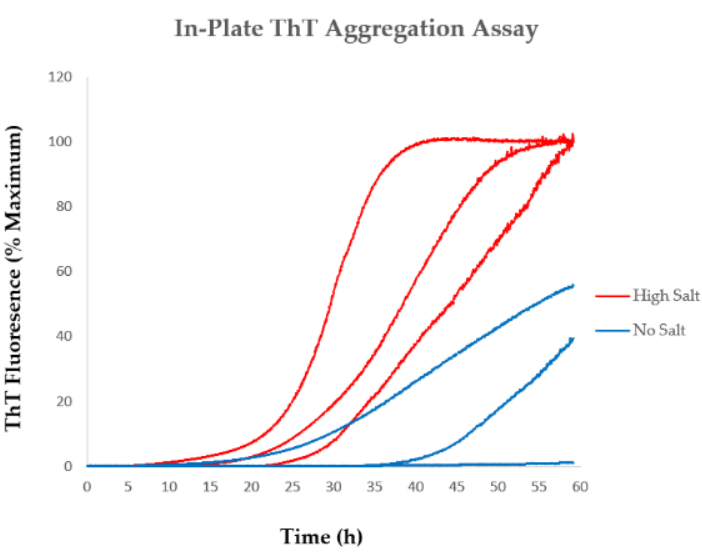

Figure 1. Effect of cell lysis buffer on the aSyn aggregation assays. (a) aSyn purity after AEX checked by SDS-PAGE and Coomassie staining. A total of $5 \mu \mathrm{g}$ of AEX-purified aSyn from both extraction methods were loaded to the gel. (b) SEC chromatogram of aSyn after AEX. (c) Aggregation profiles of aSyn purified using differently extracted cell lysates monitored by changes in ThT fluorescence over time. $N=3$ and each $N$ represents an individually produced aSyn batch.

\section{Collaborative Efforts Will Help with Comparing and Standardizing aSyn Production}

Given that recombinantly produced aSyn is widely used for modeling PD-related pathology in cell- and animal models, and for in vitro studies of aSyn biology, a great deal of attention has been directed towards the preparation and characterization of aSyn PFFs species that are used for subsequent applications. The Michael J Fox Foundation has put forward suggestions for a standard protocol for production and thorough characterization 
of these species. Therefore, since (i) the morphology of aSyn aggregates is sensitive to environmental parameters including $\mathrm{pH}$, biomolecules, and salt, and (ii) distinct strain characteristics seem to have the ability of being propagated, monomeric aSyn must be produced with great care and under standardized conditions in order to ensure aSyn quality and purity, and to reduce inter-laboratory variability that complicates the interpretation of findings (Figure 2). Therefore, we recommend true collaborative efforts between different laboratories in order to (i) systematically compare the impact of key steps in the production and purification protocols used and (ii) to develop a more general protocol with minimal variations in order to improve aSyn research, enabling the community to investigate both the physiology and pathophysiology of aSyn.

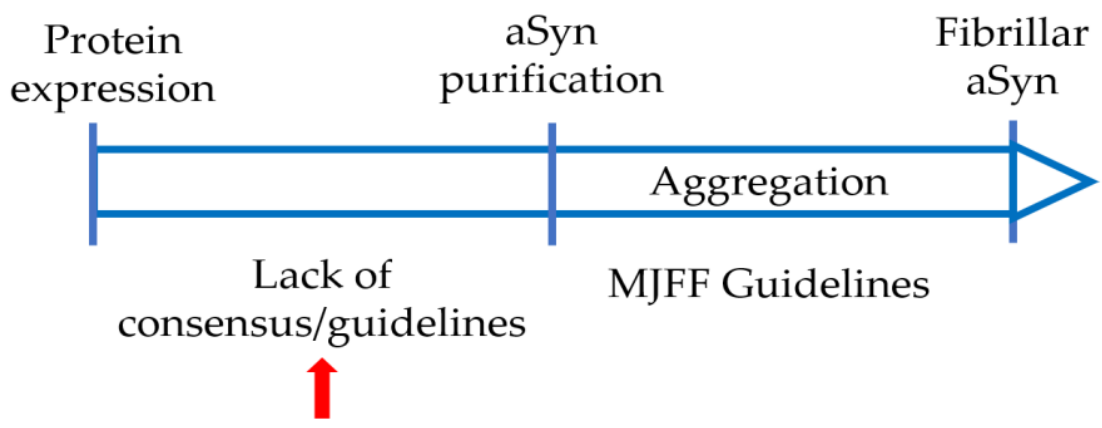

Figure 2. A schematic summary of the process of aSyn expression, purification, and aggregation. The red arrow points at the process of aSyn purification, where there is a lack of consensus, which is the focus of this study.

\section{Materials and Methods}

\subsection{Expression and Purification of aSyn}

Plasmid pET21-aSyn, containing human aSyn cDNA was transformed into competent E. coli BL21-DE3 (Sigma) on ampicillin agar plates, and one colony was used to create the bacterial cultures. Cultures of E. coli in $2 x$ LB medium containing ampicillin $(200 \mu \mathrm{g} / \mathrm{mL})$ were grown at $37^{\circ} \mathrm{C}$ with shaking. Expression was induced for $2 \mathrm{~h}$ at $\mathrm{OD}_{600} 0.5-0.6$ with $1 \mathrm{mM}$ of isopropyl $\beta$-thiogalactopyranoside (IPTG). Bacteria were pelleted by centrifugation at $6600 \mathrm{~g}$ for $15 \mathrm{~min}$ and lysed on ice in either "high salt buffer" (10 mM Tris pH7.6, $750 \mathrm{mM}$ $\mathrm{NaCl}, 1 \mathrm{mM}$ EDTA with protease inhibitor (cOmplete, Roche)) or "No salt buffer" (10 mM Tris pH7.6, $750 \mathrm{mM} \mathrm{NaCl}, 1 \mathrm{mM}$ EDTA with protease inhibitor). Lysates were sonicated on ice for a total of $5 \mathrm{~min}$ ( $30 \mathrm{~s}$ on, $30 \mathrm{~s}$ off pulses, $60 \%$ power), and boiled for $15 \mathrm{~min}$ at $95^{\circ} \mathrm{C}$. Boiled protein samples were then centrifuged, and the supernatant containing aSyn was collected. After dialysis into 10 mM TRIS pH 7.6, 1 mM EDTA, $50 \mathrm{mM} \mathrm{NaCl}$, supernatants were purified with anion exchange chromatography (HiTrap Q HP, GE Healthcare) using a mobile phase of $25 \mathrm{mM}$ Tris $\mathrm{pH} 7.6$ and a linear gradient of 9 column volumes of elution buffer to $1 \mathrm{M} \mathrm{NaCl}$ on an Äkta Pure 25M (Cytiva). "No salt" extracted protein sample was loaded directly to the anion exchange column without dialysis. Fractions containing pure aSyn were identified on a Coomassie-stained SDS-PAGE, pooled, and extensively dialyzed into water. Following lyophilization (Zirbus), protein was stored at -20 until further use. aSyn concentration was estimated by measuring protein absorbance at $280 \mathrm{~nm}$ using the molar extinction coefficient $5960 \mathrm{M}^{-1} \mathrm{~cm}^{-1}$. Protein purity was checked by running $5 \mathrm{ug}$ of each sample on 15\% SDS-PAGE gel and staining the gel with Coomassie dye. Before lyophilization, $500 \mu \mathrm{L}$ of each condition were loaded to superdex 200 column (Cytiva) to further check the protein purity.

\subsection{Thioflavin-T-Based Aggregation Assays}

aSyn was dissolved in $50 \mathrm{mM}$ HEPES (pH 7.4), $100 \mathrm{mM} \mathrm{NaCl}$, filtered through $0.2 \mathrm{um}$ Spin Filters (Corning Incorporated), and centrifuged at $20,000 \times g$ for $20 \mathrm{~min}$ at $4{ }^{\circ} \mathrm{C}$ to remove any possible insoluble aggregates. Then, $10 \mathrm{mM}$ ThT (Sigma-Aldrich, St. Louis, MO, USA) was added to $100 \mu \mathrm{L}$ of aSyn $(1 \mathrm{mg} / \mathrm{mL})$. Samples were loaded onto black 
96-well plates (Corning Incorporated, Seattle, WA, USA)) and covered with sealing tape. Plates were incubated at $42{ }^{\circ} \mathrm{C}$ with one minute orbital shaking at $432 \mathrm{rpm}$, and a $3.6 \mathrm{~min}$ waiting period for 985 cycles. Fluorescence was measured every cycle using a Tecan plate reader (Infinite M200 fluorescence plate reader, TECAN). Excitation was set at $440 \mathrm{~nm}$ with 20 flashes, and the ThT fluorescence intensity was measured at $480 \mathrm{~nm}$ emission, a 100 gain value. Four wells were used per condition. Data were normalized to the sample with the maximum fluorescence intensity for each plate.

Author Contributions: Conceptualization, M.A.-A., A.K. and T.F.O.; methodology, M.A.-A. and A.K.; formal analysis, M.A.-A. and A.K.; writing-original draft preparation, A.K.; writing-review and editing, M.A.-A., A.K. and T.F.O. All authors have read and agreed to the published version of the manuscript.

Funding: TFO was funded by the BMBF through the EU Joint Programme on Neurodegenerative Disease Research (JPND, www.jpnd.edu) project (aSynProtec). TFO is currently supported by the Deutsche Forschungsgemeinschaft (DFG, German Research Foundation) under Germany's Excellence Strategy-EXC 2067/1-390729940, SFB1286 Project B8, and BMBF through the EU Joint Programme on Neurodegenerative Disease Research (JPND, www.jpnd.edu) project (OligoFit).

Institutional Review Board Statement: Not applicable.

Informed Consent Statement: Not applicable.

Data Availability Statement: Not applicable.

Conflicts of Interest: The authors declare no conflict of interest.

\section{References}

1. Pinho, R.; Paiva, I.; Jerčić, K.G.; Fonseca-Ornelas, L.; Gerhardt, E.; Fahlbusch, C.; Esparcia, P.G.; Kerimoglu, C.; Pavlou, M.A.S.; Villar-Piqué, A.; et al. Nuclear localization and phosphorylation modulate pathological effects of alpha-Synuclein. Hum. Mol. Genet. 2019, 28, 31-50. [CrossRef] [PubMed]

2. Galvin, J.E.; Schuck, T.M.; Lee, V.M.-Y.; Trojanowski, J.Q. Differential expression and distribution of $\alpha$-, $\beta$-, and $\gamma$-synuclein in the developing human substantia nigra. Exp. Neurol. 2001, 168, 347-355. [CrossRef] [PubMed]

3. Torres, C.M.; Wassouf, Z.; Zafar, F.; Sastre, D.; Outeiro, T.; Schüle, B. The role of alpha-Synuclein and other parkinson's genes in neurodevelopmental and neurodegenerative disorders. Int. J. Mol. Sci. 2020, 21, 5724. [CrossRef] [PubMed]

4. Fauvet, B.; Mbefo, M.K.; Fares, M.-B.; Desobry, C.; Michael, S.; Ardah, M.T.; Tsika, E.; Coune, P.; Prudent, M.; Lion, N.; et al. Alpha-Synuclein in central nervous system and from erythrocytes, mammalian cells, and Escherichia coli exists predominantly as disordered monomer. J. Biol. Chem. 2012, 287, 15345-15364. [CrossRef] [PubMed]

5. Braak, H.; De Vos, R.A.; Bohl, J.; Del Tredici, K. Gastric alpha-Synuclein immunoreactive inclusions in Meissner's and Auerbach's plexuses in cases staged for Parkinson's disease-related brain pathology. Neurosci. Lett. 2006, 396, 67-72. [CrossRef]

6. Shannon, K.M.; Keshavarzian, A.; Dodiya, H.B.; Jakate, S.; Kordower, J.H. Is alpha-Synuclein in the colon a biomarker for premotor Parkinson's Disease? Evidence from 3 cases. Mov. Disord. 2012, 27, 716-719. [CrossRef]

7. Shannon, K.M.; Keshavarzian, A.; Mutlu, E.; Ms, H.B.D.; Daian, D.; Rn, J.A.J.; Kordower, J.H. Alpha-synuclein in colonic submucosa in early untreated Parkinson's disease. Mov. Disord. 2011, 27, 709-715. [CrossRef]

8. Donadio, V.; Incensi, A.; Leta, V.; Giannoccaro, M.; Scaglione, C.; Cappellari, S.; Avoni, P.; Baruzzi, A.; Liguori, R. Skin nerve alpha-Synuclein deposits: A biomarker for idiopathic Parkinson's disease. Clin. Neurophysiol. 2015, 126. [CrossRef]

9. Miranda, H.V.; Cássio, R.; Guedes, L.C.; Gomes, M.A.; Chegão, A.; Miranda, E.; Soares, T.; Coelho, M.; Rosa, M.M.; Ferreira, J.J.; et al. Posttranslational modifications of blood-derived alpha-Synuclein as biochemical markers for Parkinson's disease. Sci. Rep. 2017, 7, 13713. [CrossRef]

10. Weinreb, P.H.; Zhen, W.; Poon, A.W.; Conway, K.A.; Lansbury, P.T. NACP, A protein implicated in Alzheimer's disease and learning, is natively unfolded. Biochemistry 1996, 35, 13709-13715. [CrossRef]

11. Kim, J. Evidence that the precursor protein of non-Ap component of Alzheimer's disease amyloid (NACP) has an extended structure primarily composed of random-coil. Mol. Cells 1997, 7, 78-83. [PubMed]

12. Chandra, S.; Chen, X.; Rizo, J.; Jahn, R.; Südhof, T.C. A broken $\alpha$-helix in folded alpha-Synuclein. J. Biol. Chem. 2003, 278, 15313-15318. [CrossRef]

13. Vilar, M.; Chou, H.T.; Lührs, T.; Maji, S.K.; Riek-Loher, D.; Verel, R.; Manning, G.; Stahlberg, H.; Riek, R. The Fold of alphaSynuclein Fibrils. Proc. Natl. Acad. Sci. USA 2008, 105, 8637-8642. [CrossRef] [PubMed]

14. Hoyer, W.; Antony, T.; Cherny, D.; Heim, G.; Jovin, T.M.; Subramaniam, V. Dependence of alpha-Synuclein aggregate morphology on solution conditions. J. Mol. Biol. 2002, 322, 383-393. [CrossRef] 
15. Peelaerts, W.; Bousset, L.; Van der Perren, A.; Moskalyuk, A.; Pulizzi, R.; Giugliano, M.; Van den Haute, C.; Melki, R.; Baekelandt, V. Alpha-Synuclein strains cause distinct synucleinopathies after local and systemic administration. Nature 2015, 522, 340-344. [CrossRef] [PubMed]

16. Van Der Perren, A.; Gelders, G.; Fenyi, A.; Bousset, L.; Brito, F.; Peelaerts, W.; Haute, C.V.D.; Gentleman, S.; Melki, R.; Baekelandt, V. The structural differences between patient-derived alpha-Synuclein strains dictate characteristics of Parkinson's disease, multiple system atrophy and dementia with Lewy bodies. Acta Neuropathol. 2020, 139, 977-1000. [CrossRef]

17. Strohäker, T.; Jung, B.C.; Liou, S.-H.; Fernandez, C.O.; Riedel, D.; Becker, S.; Halliday, G.M.; Bennati, M.; Kim, W.S.; Lee, S.-J.; et al. Structural heterogeneity of alpha-Synuclein fibrils amplified from patient brain extracts. Nat. Commun. 2019, 10, 1-12. [CrossRef]

18. Luk, K.C.; Song, C.; O’Brien, P.; Stieber, A.; Branch, J.R.; Brunden, K.R.; Trojanowski, J.Q.; Lee, V.M.-Y. Exogenous alpha-Synuclein fibrils seed the formation of lewy body-like intracellular inclusions in cultured cells. Proc. Natl. Acad. Sci. USA 2009, 106, 20051-20056. [CrossRef]

19. Volpicelli-Daley, L.A.; Luk, K.C.; Lee, V.M.-Y. Addition of exogenous alpha-Synuclein preformed fibrils to primary neuronal cultures to seed recruitment of endogenous alpha-Synuclein to Lewy body and Lewy neurite-like aggregates. Nat. Protoc. 2014, 9 , 2135-2146. [CrossRef]

20. Volpicelli-Daley, L.A.; Luk, K.C.; Patel, T.P.; Tanik, S.A.; Riddle, D.M.; Stieber, A.; Meaney, D.F.; Trojanowski, J.Q.; Lee, V.M.Y. Exogenous alpha-Synuclein fibrils induce lewy body pathology leading to synaptic dysfunction and neuron death. Neuron 2011, 72, 57-71. [CrossRef]

21. Luk, K.; Kehm, V.M.; Zhang, B.; O’Brien, P.; Trojanowski, J.Q.; Lee, V.M. Intracerebral inoculation of pathological alpha-Synuclein initiates a rapidly progressive neurodegenerative alpha-Synucleinopathy in mice. J. Exp. Med. 2012, 209, 975-986. [CrossRef] [PubMed]

22. Paumier, K.L.; Luk, K.; Manfredsson, F.P.; Kanaan, N.; Lipton, J.W.; Collier, T.J.; Steece-Collier, K.; Kemp, C.J.; Celano, S.; Schulz, E.; et al. Intrastriatal injection of pre-formed mouse alpha-Synuclein fibrils into rats triggers alpha-Synuclein pathology and bilateral nigrostriatal degeneration. Neurobiol. Dis. 2015, 82, 185-199. [CrossRef] [PubMed]

23. Polinski, N.K.; Volpicelli-Daley, L.A.; Sortwell, C.E.; Luk, K.C.; Cremades, N.; Gottler, L.M.; Froula, J.; Duffy, M.F.; Lee, V.M.; Martinez, T.N.; et al. Best practices for generating and using alpha-Synuclein pre-formed fibrils to model Parkinson's disease in rodents. J. Park. Dis. 2018, 8, 303-322. [CrossRef] [PubMed]

24. Fairfoul, G.; McGuire, L.I.; Pal, S.; Ironside, J.W.; Neumann, J.; Christie, S.; Joachim, C.; Esiri, M.; Evetts, S.G.; Rolinski, M.; et al. Alpha-synuclein RT -Qu IC in the CSF of patients with alpha-Synucleinopathies. Ann. Clin. Transl. Neurol. 2016, 3, 812-818. [CrossRef] [PubMed]

25. Shahnawaz, M.; Tokuda, T.; Waragai, M.; Mendez, N.; Ishii, R.; Trenkwalder, C.; Mollenhauer, B.; Soto, C. Development of a biochemical diagnosis of Parkinson disease by detection of alpha-Synuclein misfolded aggregates in cerebrospinal fluid. JAMA Neurol. 2017, 74, 163-172. [CrossRef]

26. Van Rumund, A.; Green, A.J.E.; Fairfoul, G.; Esselink, R.A.J.; Bloem, B.R.; Verbeek, M.M. Alpha-Synuclein real-time quakinginduced conversion in the cerebrospinal fluid of uncertain cases of parkinsonism. Ann. Neurol. 2019, 85, 777-781. [CrossRef]

27. Kang, U.J.; Boehme, A.K.; Bs, G.F.; Shahnawaz, M.; Ma, T.; Hutten, S.J.; Green, A.; Soto, C. Comparative study of cerebrospinal fluid alpha-Synuclein seeding aggregation assays for diagnosis of Parkinson's disease. Mov. Disord. 2019, 34, 536-544. [CrossRef]

28. Rossi, M.; Candelise, N.; Baiardi, S.; Capellari, S.; Giannini, G.; Orrù, C.D.; Antelmi, E.; Mammana, A.; Hughson, A.G.; CalandraBuonaura, G.; et al. Ultrasensitive RT-QuIC assay with high sensitivity and specificity for Lewy body-associated synucleinopathies. Acta Neuropathol. 2020, 140, 49-62. [CrossRef]

29. Paciotti, S.; Bellomo, G.; Gatticchi, L.; Parnetti, L. Are We Ready for Detecting alpha-Synuclein prone to aggregation in patients? The case of "Protein-Misfolding Cyclic Amplification" and "Real-Time Quaking-Induced Conversion" as diagnostic tools. Front. Neurol. 2018, 9, 415. [CrossRef]

30. Brockmann, K.; Quadalti, C.; Lerche, S.; Rossi, M.; Wurster, I.; Baiardi, S.; Roeben, B.; Mammana, A.; Zimmermann, M.; Hauser A.-K.; et al. Association between CSF alpha-Synuclein seeding activity and genetic status in Parkinson's disease and dementia with Lewy bodies. Acta Neuropathol. Commun. 2021, 9, 1-11. [CrossRef]

31. Perra, D.; Bongianni, M.; Novi, G.; Janes, F.; Bessi, V.; Capaldi, S.; Sacchetto, L.; Tagliapietra, M.; Schenone, G.; Morbelli, S.; et al. Alpha-synuclein seeds in olfactory mucosa and cerebrospinal fluid of patients with dementia with Lewy bodies. Brain Commun. 2021, 3, fcab045. [CrossRef]

32. Poggiolini, I.; Gupta, V.; Lawton, M.; Lee, S.; El-Turabi, A.; Querejeta-Coma, A.; Trenkwalder, C.; Sixel-Döring, F.; Foubert-Samier, A.; Pavy, A.; et al. Diagnostic value of cerebrospinal fluid alpha-Synuclein seed quantification in synucleinopathies. Brain J. Neurol. 2021, awab431. [CrossRef]

33. Russo, M.J.; Orru, C.D.; Concha-Marambio, L.; Giaisi, S.; Groveman, B.R.; Farris, C.M.; Holguin, B.; Hughson, A.G.; LaFontant, D.-E.; Caspell-Garcia, C.; et al. High diagnostic performance of independent alpha-Synuclein seed amplification assays for detection of early Parkinson's disease. Acta Neuropathol. Commun. 2021, 9, 1-13. [CrossRef]

34. Oliveira, L.M.A.; Gasser, T.; Edwards, R.; Zweckstetter, M.; Melki, R.; Stefanis, L.; Lashuel, H.A.; Sulzer, D.; Vekrellis, K.; Halliday, G.M.; et al. Alpha-synuclein research: Defining strategic moves in the battle against Parkinson's disease. NPJ Park. Dis. 2021, 7, 1-23. [CrossRef]

35. Fauvet, B.; Fares, M.-B.; Samuel, F.; Dikiy, I.; Tandon, A.; Eliezer, D.; Lashuel, H.A. Characterization of semisynthetic and naturally $\mathrm{N} \alpha$-acetylated alpha-Synuclein in vitro and in intact cells. J. Biol. Chem. 2012, 287, 28243-28262. [CrossRef] 
36. Theillet, F.-X.; Binolfi, A.; Bekei, B.; Martorana, A.; Rose, H.M.; Stuiver, M.; Verzini, S.; Lorenz, D.; van Rossum, M.; Goldfarb, D.; et al. Structural disorder of monomeric alpha-Synuclein persists in mammalian cells. Nature 2016, 530, 45-50. [CrossRef]

37. Bousset, L.; Pieri, L.; Ruiz-Arlandis, G.; Gath, J.; Jensen, P.H.; Habenstein, B.; Madiona, K.; Olieric, V.; Böckmann, A.; Meier, B.H.; et al. Structural and functional characterization of two alpha-Synuclein strains. Nat. Commun. 2013, 4, 2575. [CrossRef]

38. De Giorgi, F.; Laferrière, F.; Zinghirino, F.; Faggiani, E.; Lends, A.; Bertoni, M.; Yu, X.; Grélard, A.; Morvan, E.; Habenstein, B.; et al. Novel self-replicating alpha-Synuclein polymorphs that escape ThT monitoring can spontaneously emerge and acutely spread in neurons. Sci. Adv. 2020, 6, eabc4364. [CrossRef]

39. Giehm, L.; Lorenzen, N.; Otzen, D.E. Assays for alpha-Synuclein aggregation. Methods 2011, 53, 295-305. [CrossRef]

40. Huang, C.; Ren, G.; Zhou, H.; Wang, C.-C. A new method for purification of recombinant human alpha-Synuclein in Escherichia coli. Protein Expr. Purif. 2005, 42, 173-177. [CrossRef]

41. Conway, K.A.; Harper, J.D.; Lansbury, P.T. Accelerated in vitro fibril formation by a mutant alpha-Synuclein linked to early-onset Parkinson disease. Nat. Med. 1998, 4, 1318-1320. [CrossRef]

42. Narhi, L.; Wood, S.J.; Steavenson, S.; Jiang, Y.; Wu, G.M.; Anafi, D.; Kaufman, S.A.; Martin, F.; Sitney, K.; Denis, P. Both familial Parkinson's disease mutations accelerate alpha-Synuclein aggregation. J. Biol. Chem. 1999, 274, 9843-9846. [CrossRef]

43. Campioni, S.; Carret, G.; Jordens, S.; Nicoud, L.; Mezzenga, R.; Riek, R. The presence of an air-water interface affects formation and elongation of alpha-Synuclein fibrils. J. Am. Chem. Soc. 2014, 136, 2866-2875. [CrossRef]

44. Kumar, S.T.; Jagannath, S.; Francois, C.; Vanderstichele, H.; Stoops, E.; Lashuel, H.A. How specific are the conformation-specific alpha-Synuclein antibodies? Characterization and validation of 16 alpha-Synuclein conformation-specific antibodies using well-characterized preparations of alpha-Synuclein monomers, fibrils and oligomers with distinct structures and morphology. Neurobiol. Dis. 2020, 146, 105086. [CrossRef]

45. Der-Sarkissian, A.; Jao, C.C.; Chen, J.; Langen, R. Structural Organization of alpha-Synuclein fibrils studied by site-directed spin labeling. J. Biol. Chem. 2003, 278, 37530-37535. [CrossRef]

46. Ghee, M.; Melki, R.; Michot, N.; Mallet, J. PA700, the regulatory complex of the 26S proteasome, interferes with alpha-Synuclein assembly. FEBS J. 2005, 272, 4023-4033. [CrossRef]

47. Galesic, A.; Rakshit, A.; Cutolo, G.; Pacheco, R.P.; Balana, A.T.; Moon, S.P.; Pratt, M.R. Comparison of N-acetyl-glucosamine to other monosaccharides reveals structural differences for the inhibition of alpha-Synuclein aggregation. ACS Chem. Biol. 2021, 16, 14-19. [CrossRef]

48. Fares, M.B.; Maco, B.; Oueslati, A.; Rockenstein, E.; Ninkina, N.; Buchman, V.L.; Masliah, E.; Lashuel, H.A. Induction of de novo alpha-Synuclein fibrillization in a neuronal model for Parkinson's disease. Proc. Natl. Acad. Sci. USA 2016, 113, E912-E921. [CrossRef]

49. Stephens, A.D.; Nespovitaya, N.; Zacharopoulou, M.; Kaminski, C.; Phillips, J.J.; Schierle, G.S.K. Different structural conformers of monomeric alpha-Synuclein identified after lyophilizing and freezing. Anal. Chem. 2018, 90, 6975-6983. [CrossRef]

50. Stephens, A.D.; Zacharopoulou, M.; Moons, R.; Fusco, G.; Seetaloo, N.; Chiki, A.; Woodhams, P.J.; Mela, I.; Lashuel, H.A.; Phillips, J.J.; et al. Extent of N-terminus exposure of monomeric alpha-Synuclein determines its aggregation propensity. Nat. Commun. 2020, 11, 1-15. [CrossRef]

51. Stephens, A.D.; Matak-Vinkovic, D.; Fernandez-Villegas, A.; Schierle, G.S.K. Purification of recombinant alpha-Synuclein: A comparison of commonly used protocols. Biochemistry 2020, 59, 4563-4572. [CrossRef]

52. Giasson, B.I.; Murray, I.V.; Trojanowski, J.Q.; Lee, V.M. A hydrophobic stretch of 12 amino acid residues in the middle of alpha-Synuclein is essential for filament assembly. J. Biol. Chem. 2001, 276, 2380-2386. [CrossRef] 